\title{
Sucrose non-ferment 1 related protein kinase 2 (SnRK2) genes could mediate the stress responses in potato (Solanum tuberosum L.)
}

Jiangping Bai ${ }^{1,2^{*}+}$, Juan Mao ${ }^{1,3+}$, Hongyu Yang ${ }^{1,3}$, Awais Khan ${ }^{4}$, Aqi Fan², Siyan Liu², Junlian Zhang ${ }^{1,3}$, Di Wang ${ }^{1,2}$, Huijuan Gao ${ }^{5}$ and Jinlin Zhang ${ }^{1,5^{*}}$

\begin{abstract}
Background: The SnRKs (sucrose non-fermenting 1 related protein kinase) are a gene family coding for Ser/Thr protein kinases and play important roles in linking the tolerance and metabolic responses of plants to abiotic stresses. To date, no genome-wide characterization of the sucrose non-ferment 1 related protein kinase 2 (SnRK2) subfamily has been conducted in potato (Solanum tuberosum L.).

Results: In this study, eight StSnRK2 genes (StSnRK2.1- StSnRK2.8) were identified in the genome of the potato (Solanum tuberosum L.) cultivar 'Longshu 3', with similar characteristics to SnRK2 from other plant species in gene structure, motif distribution and secondary structures. The C-terminal regions were highly divergent among StSnRK2S, while they all carried the similar Ser/Thr protein kinase domain. The fluorescence of GFP fused with StSnRK2.1, StSnRK2.2, StSnRK2.6, StSnRK2.7 and StSnRK2.8 was detected in the nucleus and cytoplasm of onion epidermal cells with StSnRK2.3 and StSnRK2.4 mainly associated to the nucleus while StSnRK2.5 to subcellular organelles. Expression level analysis by qRT-PCR showed that StSnRK2.1, 2.2, 2.5 and 2.6 were more than 1 fold higher in the root than in the leaf, tuber and stem tissues. The expressions of StSnRK2.3, 2.7, and 2.8 were at least 1. 5 folds higher in the leaf and stem than in the root, but lower in the tuber. The expression of StSnRK2.4 was also significantly $(P<0.05)$ higher in leaf, stem, and tuber than in the root. From the perspective of the relative expressions of StSnRK2 genes in potato, ABA treatment had a different effect from $\mathrm{NaCl}$ and PEG treatments.

Conclusion: In the present study, we identified and characterized eight SnRK2s in the potato genome. The eight StSnRK2s exhibit similar gene structure and secondary structures in potato to the SnRK2s found in other plant species. The relative expression of eight genes varied among various tissues (roots, leaves, tubers, and stems) and abiotic stresses (ABA, NaCl and PEG-6000) with the prolongation of treatments. This study provides valuable information for the future functional dissection of potato SnRK2 genes in stress signal transduction, plant growth and development.
\end{abstract}

Keywords: Potato, StSnRK2, Stress responses, ABA, NaCl, PEG-6000

\footnotetext{
* Correspondence: baijp@gsau.edu.cn; jlzhang@lzu.edu.cn

${ }^{\dagger}$ Equal contributors

'Gansu Key Lab of Crop Improvement \& Germplasm Enhancement, Gansu

Provincial Key Lab of Aridland Crop Science, Lanzhou 730070, Gansu,

People's Republic of China

Full list of author information is available at the end of the article
} 


\section{Background}

In many regions of the world, potato (Solanum tuberosum L.) production is seriously threatened by abiotic stresses such as frequent drought and salinity [1]. Plant drought tolerance is a complex response and involves the comprehensive interactions of numerous genes, proteins and metabolites in plant cells. Systematic analysis of the plant cell network responsible for drought stress tolerance is a promising approach for the development of drought tolerant plants $[1,2]$. Protein phosphorylation is involved in regulation of various cellular activities in plants and one of the main signals mediating the responses to environmental stresses [3-7]. The SnRKs (sucrose non-fermenting 1 related protein kinase) are a gene family coding for Ser/Thr protein kinases and play important roles in linking abiotic stress tolerance and the metabolic responses of plants [8-10]. Based on sequence similarity, domain structure and metabolic roles, the plant SnRK family is divided into three subfamilies: SnRK1, SnRK2 and SnRK3. Many studies have demonstrated that these three subfamilies play various roles in the metabolism and development of plants. SnRK1 plays an important role in regulating carbon metabolism and energy conversion in plants $[11,12]$, while SnRK3 is involved in plant development, calcium-responsive regulatory loop and abscisic acid (ABA) sensitivity. SnRK2 members are the major players in plant responses to osmotic stresses [13-16], ABA dependent and independent stomatal closure-opening [17], fruit development [18], seed dormancy [19] and germination [20, 21].

Since the first $S n R K 2$ (PKABA1) gene was identified in wheat [22], the members of the SnRK2 subfamily have been subsequently identified in many other plant species such as Arabidopsis [23, 24], rice [25], maize [26], tobacco [27], wheat [28, 29], sorghum [30], soybean [31, 32], barley [33] and grape [34]. In Arabidopsis, nine of the ten SnRK2 members (except for $S n R K 2.9$ ) can be activated by osmotic stress [13]. Among them, SnRK2.8 and SnRK2.7 play a critical role in regulating the expression of droughtresponsive genes [35]. In rice, all the ten $S n R K 2$ members (designated as SAPK1 to SAPK10, stress/ABA-activated protein kinase) are activated by hyperosmotic stress with three of them (SAPK8, SAPK9, and SAPK10) also activated by $A B A[25,36]$. In maize, all the ten characterized members of SnRK2 are stress-related [26]. In wheat, osmotic stress and ABA-induced gene expression were linked with the activity of SnRK2 members [28, 29]. However, little is known about the functions of $S n R K 2 s$ in potato and there is no information on how $S n R K 2$ family genes are involved in the tolerance of potato to osmotic stress.

In this study, we identified and characterized eight $S n R K 2$ genes from the potato genome (named StSnRK2.1, StSnRK2.2, StSnRK2.3, StSnRK2.4, StSnRK2.5, StSnRK2.6,
StSnRK2.7 and StSnRK2.8), then analyzed their tissuespecific and stress-induced expression profiles. To better understand their mechanisms underlying improved abiotic stress tolerance of the StSnRK2 gene family, the subcellular localization of StSnRK2 proteins, the expression patterns of the eight $S n R K 2 s$ gene members and physiological index analysis of potato plantlets responding to $\mathrm{ABA}$ $(50 \mu \mathrm{M}), \mathrm{NaCl}(200 \mathrm{mM})$ and PEG-6000 (5\%) were performed. This study established functions for the potato SnRK2 gene family and provides a foundation for further clarifying the mechanism of potato stress resistance. The results will also provide genetic foundations for developing drought tolerant potato cultivars via manipulating SnRK2 gene family.

\section{Methods}

Plant material

One the local main potato cultivars, 'Longshu 3' released by Gansu Academy of Agricultural Sciences, Lanzhou, China, was used in the study. This cultivar is widely grown in northwestern China because of its moderate resistance to low temperatures, drought and salinity. Potato plantlets were propagated in MS medium [37]. A total of 6-8 plantlets were cultured in each $150 \mathrm{ml}$ flask at an illumination intensity of $200 \mu \mathrm{mol} \mathrm{m} \mathrm{m}^{-1}$ under the temperature of $23 \pm 2{ }^{\circ} \mathrm{C}$ with a photoperiod of $16 \mathrm{~h} / 8 \mathrm{~h}$ (day/night).

\section{Identification and cloning of potato StSnRK2s}

The coding sequences of $S n R K 2 s$ from Arabidopsis, maize, and rice were obtained through literature and the genbank (http://www.ncbi.nlm.nih.gov) (Additional file 1: Table S1). To identify the $S n R K 2$ genes in potato, we looked for the highly conserved sequences of $S n R K 2 s$ in the Potato Genome Sequencing Consortium database (http://potatogenome.net/index.php/Main_Page).

To clone the cDNA sequences, total RNA was extracted from the potato plantlets using the RNA simple Total RNA Kit (TIANGEN). The quality and quantity of RNA were measured by both electrophoresis and optical absorbency (Nanophotometer, Implen). The cDNA was synthesized from the total RNA following the instruction of the Kit cDNA MMLV (Sangon). Full-length coding sequences of $S t S n R K 2$ genes were amplified via PCR with the primers presented in Additional file 1: Table S2. The PCR products were inserted into pGEM-T easy cloning vector and propagated in Escherichia coli DH5 $\alpha$ (Promega) for sequencing and conservation.

\section{Phylogenetic analysis}

The $S n R K 2 s$ from Arabidopsis, rice, maize and potato were aligned using ClustalX1.81 (ftp://ftp-igbmc.u-strasbg.fr/ pub/ClustalX). The final view of the alignment was manually adjusted with Jalview (2.07) [38]. The phylogenetic tree 
was constructed using the neighbor-joining (NJ) method in MEGA 5 [39]. Bootstrap analysis was performed using 1000 replicates to evaluate the reliability of different phylogenetic groups.

\section{Characterization of StSnRK2 genes and proteins}

The genomic sequences were identified from Potato Genome Sequencing Consortium database (http://potatogenome.net/index.php/Main_Page). The gene structures (exon and intron) were analyzed with splign (http://www.ncbi.nlm.nih.gov/sutils/splign) [40]. The promoter sequences were identified about $2 \mathrm{~kb}$ upstream of the transcription start site of each gene, and the abiotic stress-associated elements (ABRE, DRE/CRT, and LTRE) were obtained from the PLACE database (http://www.dna.affrc.go.jp/) [41]. The secondary structure of the deduced polypeptide was predicted using the programs of SOPMA which listed in Expasy (www.EXPASY.org)

\section{Subcellular localization of StSnRK2s}

To determine the subcellular localization of the StSnRK2s, full-length of StSnRK2s were inserted into the $\mathrm{KpnI} / \mathrm{BamHI}$ site of the pEBGFP vector to generate pEBGFP-StSnRK2. For transient expression in onion epidermal cells, the pEBGFP and pEBGFP-StSnRK2s plasmids and the constructs were introduced into onion epidermal cells using Agrobacterium tumefaciens-mediated transformation methods. Onion epidermal tissues were subsequently incubated on solid MS medium in the dark at $26{ }^{\circ} \mathrm{C}$ for $48 \mathrm{~h}$. Localization of fluorescent proteins in onion epidermal cells was observed by a Zeiss LSM 710/ConfoCor2 laser-scanning imaging system (CarlZeiss, Jena, Germany). Fluorescence was detected between 505 and $550 \mathrm{~nm}$ with excitation at $488 \mathrm{~nm}$. GFP fluorescence and light field vision were recorded in separate channels and then merged into an overlay image.

\section{Expression profile of StSnRK2s in potato plants}

Four-week old potato in vitro plantlets were transferred into liquid MS medium supplemented with either $50 \mu \mathrm{M}$ ABA, $200 \mathrm{mM}$ sodium chloride $(\mathrm{NaCl})$ or $5 \%$ polyethyleneglycol (PEG-6000) to investigate the expression patterns of StSnRK2s under different stress-conditions. After incubation $24 \mathrm{~h}$, the leaves were harvested and immediately frozen in liquid nitrogen for RNA extraction. Quantitative Real-Time PCR (qRT-PCR) was conducted with SYBR Green I technology (TaKaRa), the ef1 $\alpha$ gene (AB061263) was used as internal control gene, the gene primers presented in Additional file 1: Table S2 and the relative quantification of RNA expression was selected. Three independent replicates were performed for each experiment. In each case, ten test tubes containing six to eight explants represented each treatment. For quantification, a no- template control, calibration curve and non-specific reactions were run in triplicate. The $2^{-\Delta \Delta C t}$ method $\left(C_{t}\right.$, Cycle threshold value of target gene) was selected to calculate the gene expression folds; The formulas are as follows [42, 43]:

$$
\begin{aligned}
& \Delta C_{t} \text { Test gene }=C_{t} \text { Test gene }-C_{t} \text { Housekeeping gene } \\
& \Delta C_{t \text { Control gene }}=C_{t} \text { Control gene }-C_{t} \text { Housekeeping gene }
\end{aligned}
$$

where control gene refers to those genes that were treated with only water.

$$
-\Delta \Delta C_{t}=-\left(\Delta C_{t} \text { Test gene }-\Delta C_{t} \text { Control gene }\right)
$$

Gene expression fold (Test gene/Control gene $)=2^{-\triangle \Delta C t}$.

\section{Total soluble sugar and proline content assay}

In vitro plantlets treated in the same manner as for gene expression analysis were sampled for total soluble sugar and proline content assay under different stress conditions. The total soluble sugar content in the leaves was measured by the method of Zhang et al. [44]. The total soluble sugar was extracted from $100 \mathrm{mg}$ potato leaves in boiling water and the supernatant was mixed with $80 \%$ ethanol to a final volume of $25 \mathrm{ml}$. Then, $2 \mathrm{~mL}$ of solution was mixed with $5 \mathrm{~mL}$ of anthrone reagent and the mixture was incubated at room temperature $\left(18-30{ }^{\circ} \mathrm{C}\right)$ for $15 \mathrm{~min}$. The absorbance was at $630 \mathrm{~nm}$ (UV-2600, Shomadzu) and the sugar concentration was determined from a glucose standard curve and expressed on a fresh weight base.

Proline content was assayed by the acid-ninhydrin procedure [45]. Potato leaf samples $(0.5 \mathrm{~g})$ were ground with $3 \%$ sulphosalicylic acid $(10 \mathrm{~mL})$. After centrifugation at $5000 \mathrm{rpm}$ for $10 \mathrm{~min}$, supernatant $(2 \mathrm{~mL})$ was mixed with the same volume of acidninhydrin and acetic acid, the mixture was incubated at $100{ }^{\circ} \mathrm{C}$ for $1 \mathrm{~h}$, and the reaction was stopped on ice. The mixture was extracted with $4 \mathrm{~mL}$ toluene and absorbance at $517 \mathrm{~nm}$ was determined (UV-2600, Shimadzu). The proline concentration was determined from a standard curve and expressed on a fresh weight base.

\section{Statistical analysis}

Gene expression, total soluble sugar, and proline assays were performed with three replicates and were analyzed using the Statistical Package for Social Sciences for Windows (SPSS version 17.0, SPSS Inc., Chicago, USA). Mean comparisons were performed using Tukey's multiple range test and the significance between different treatments was presented at the $P<0.05$ probability level. 


\section{Results}

Identification of StSnRK2 members in potato

A genome-wide search using $S n R K 2$ cDNA sequences of Arabidopsis, maize and rice as references to identify the eight $S n R K 2$ homologous sequences in potato genome (Solanum tuberosum group Phureja DM1-3). The genespecific primers were designed to clone the eight $S n R K 2 s$ homologous cDNA from the potato cultivar 'Longshu 3'. The candidate sequences coding potato $S n R K 2 s$ ranged from $1008 \mathrm{bp}$ to $1089 \mathrm{bp}$ (Table 1). The eight sequences were designated as StSnRK2.1, StSnRK2.2 to StSnRK2.8 and the confirmed full length cDNA were submitted to NCBI. The length of the predicted coding sequences of potato $S n R K 2 s$ ranged from $37.74 \mathrm{kDa}$ to $41.5 \mathrm{kDa}$. The protein length varied from 335 (StSnRK2.1) to 362 amino acids (StSnRK2.3). The protein length and the molecular weight of $S t S n R K 2 s$ were similar to $S n R K 2$ members reported in Arabidopsis, rice and maize (Table 1, Additional file 2: Figure S1) [14].

Based on the potato genome sequence, $S t S n R K 2$ genes were located on different chromosomes (Table 1) with StSnRK2.1 and StSnRK2.5 on chromosome 4, StSnRK2.3 and StSnRK2.4 on chromosome 1, and StSnRK2.2, StSnRK2.6, StSnRK2.7 and StSnRK2.8 on chromosomes $8,5,12$ and 11 , respectively.

\section{Gene and protein structures of StSnRK2s}

All StSnRK2s had nine exons except for StSnRK2.6 with seven exons (Fig. 1), and the first exon was around 120 bp except for StSnRK2.3 with a 177 bp first exon. The seven genes with nine exons had highly conserved exon lengths, with the length of the second through the eighth exons 75 bp, 102 bp, 54 bp, 93 bp, 93 bp, 105 bp and 99 bp, respectively. StSnRK2.6 had seven exons, and the length of the second exon showed a possible combination of the second to fourth conserved exons of the other StSnRK2 genes. The predicted secondary structure of proteins suggested that eight StSnRK proteins might share a high degree of similarity (Table 2).

\section{Phylogenetic analysis of StSnRK2}

The N-termini of StSnRK2s were almost identical, but the C-terminal regions were highly divergent (ranging from 261 to 327 aa) (Fig. 2). All StSnRK2s had a conserved Ser/ Thr protein kinase domain in the N-terminal (4 to 260 aa). Multiple alignment analysis based on the full length amino acid sequences of $37 \operatorname{SnRK2s}$ was conducted to understand the evolutionary relationship between $S t S n R K 2 s$ and other reported SnRK2s. An unrooted phylogenetic tree was constructed with the amino acid sequences, using the neighbor-joining method (Fig. 3 and Additional file 2: Figure S2). The results demonstrated that $S n R K 2 s$ are highly conserved in the plant kingdom. StSnRK2s were related to each other and could be divided into three distinct groups. The StSnRK2.1, StSnRK2.2, StSnRK2.5, StSnRK2.7 and StSnRK2.8 belonged to group I, StSnRK2.4 and $S t S n R K 2.6$ to group II and StSnRK2.3 alone to group III.

\section{Subcellular localization of StSnRK2 proteins}

To better understand the functions of StSnRK2, we transiently expressed pBEGFP-StSnRK2 fusion proteins in onion epidermal cells (Fig. 4). The epidermal cells were transformed with the 35S: GFP observed with fluorescence microscopy. Transiently expressed GFP-StSnRK2 fusion proteins were all detected in the nucleus or cytoplasm of onion epidermal cells. The fluorescence of GFP fused with $S t S n R K 2.1$, StSnRK2.2, StSnRK2.6, StSnRK2.7, and $S t S n R K 2.8$ was detected in the nucleus and cytoplasm of onion epidermal cells. On the other hand, StSnRK2.3 and StSnRK2.4 are mainly associated to the nucleus, while $S t S n R K 2.5$ seems to be associated to subcellular organelles.

Table 1 The basic properties and characteristics of StSnRK2 genes in potato

\begin{tabular}{|c|c|c|c|c|c|c|c|c|c|c|}
\hline Gene & $\mathrm{Chr}^{\mathrm{a}}$ & $\left.\mathrm{NCBI} G\right|^{b}$ & Genomic locus ${ }^{c}$ & Position $^{d}$ & $\begin{array}{l}\text { Cds } \\
(b p)^{e}\end{array}$ & $\begin{array}{l}\text { Exons } \\
(\mathrm{No})^{\mathrm{f}}\end{array}$ & $\begin{array}{l}\text { Full lengh } \\
(\mathrm{bp})^{\mathrm{g}}\end{array}$ & $\begin{array}{l}\text { Amino acid } \\
(\mathrm{aa})^{\mathrm{h}}\end{array}$ & Theoretical pl & $\mathrm{Mw}(\mathrm{kDa})^{\mathrm{j}}$ \\
\hline StSnRK2.1 & 4 & $404,435,142$ & PGSC0003DMT400079214 & $56,031,065 \ldots 56,034,492$ & 1008 & 9 & 3428 & 335 & 5.37 & 37.74 \\
\hline StSnRK2.2 & 8 & $404,435,144$ & PGSC0003DMT400067424 & $37,772,908 \ldots 37,775,887$ & 1020 & 9 & 4028 & 339 & 5.93 & 38.33 \\
\hline StSnRK2.3 & 1 & $404,435,146$ & PGSC0003DMT400066617 & $77,595,506 \ldots 77599207$ & 1089 & 9 & 3702 & 362 & 4.96 & 41.06 \\
\hline StSnRK2.4 & 1 & $404,435,148$ & PGSC0003DMT400061170 & $73,495,432 . . .73500028$ & 1083 & 9 & 4597 & 360 & 5.52 & 41.49 \\
\hline$S t S n R K 2.5$ & 4 & $404,435,150$ & PGSC0003DMT400060762 & $6,332,105 \ldots 6336032$ & 1035 & 9 & 3928 & 344 & 5.76 & 39.20 \\
\hline StSnRK2.6 & 5 & $404,435,152$ & PGSC0003DMT400060263 & $46,960,739 \ldots . .46964637$ & 1077 & 7 & 3899 & 358 & 6.08 & 41.20 \\
\hline$S t S n R K 2.7$ & 12 & $404,435,154$ & PGSC0003DMT400045810 & $53,346,801 \ldots 53350990$ & 1011 & 9 & 4190 & 336 & 5.57 & 38.40 \\
\hline StSnRK2.8 & 11 & $404,435,156$ & PGSC0003DMT400041671 & $4,225,503 \ldots 4,229,063$ & 1050 & 9 & 2561 & 349 & 4.88 & 39.85 \\
\hline
\end{tabular}

${ }^{a}$ Chromosome in which target gene is located in potato. ${ }^{b}$ Genebank index number in NCBI. ${ }^{\mathrm{c}}$ Genomic locus in potato Genome Sequencing Consortium database (http://potatogenome.net/index.php/Main_Page). ${ }^{\mathrm{d}}$ The position of genes on the corresponding list in 'Genomic locus'. 'Length of coding region in base pairs. ${ }^{f}$ The numbers of exons which were analyzed with splign (http://www.ncbi.nlm.nih.gov/sutils/splign). ${ }^{9}$ Nucleotide accession of fulllength cDNA in potato Genome Sequencing Consortium database. ${ }^{\mathrm{h}}$ Amino acid number of deduced protein. ${ }^{\mathrm{i}}$ The Theoretical pl of deduced protein. 'The molecular weight of deduced protein. 


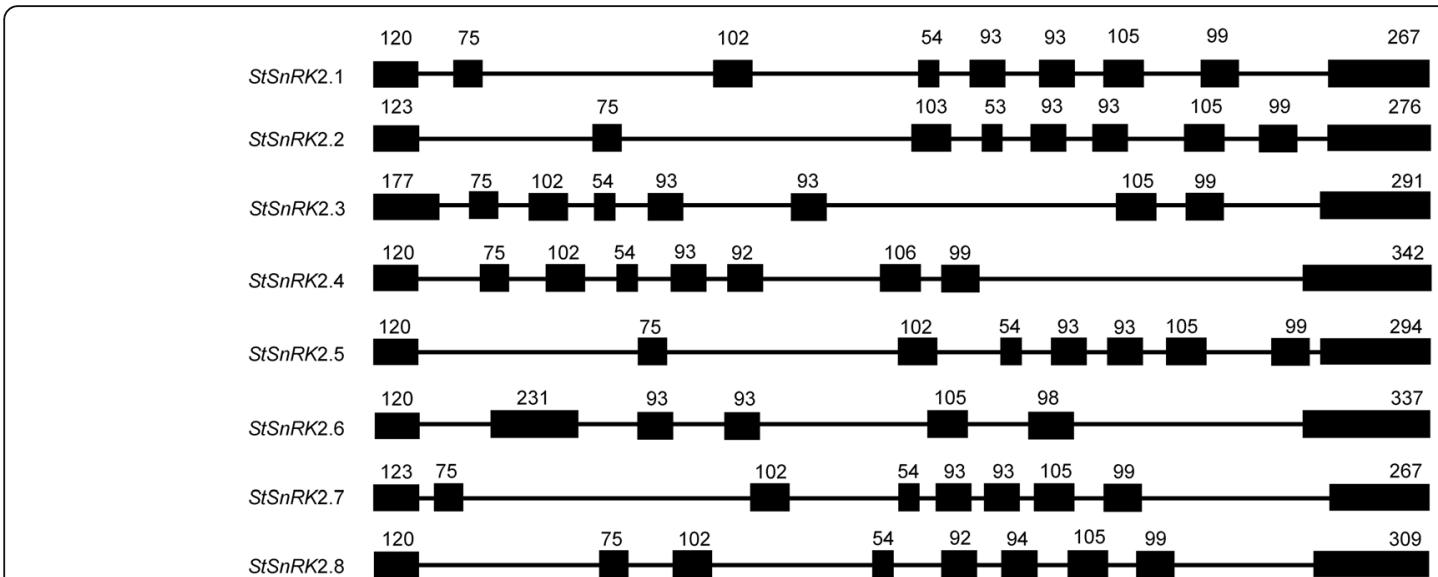

Fig. 1 Gene structures of StSnRK2s in potato. Introns and exons were represented by lines and filled boxes, respectively. The numbers above the exons indicate the length (bp) of the exons

Tissue-specific expression of StSnRK2 genes

The relative expressions of the eight StSnRK2 genes varied among tissues (root, leaf, stem and tuber) (Fig. 5). StSnRK2.1, StSnRK2.2, StSnRK2.5 and StSnRK2.6 were highest expressed in root. In contrast, the expression levels of $S t S n R K 2.3, S t S n R K 2.7$ and $S t S n R K 2.8$ in leaf and stem were significantly higher than those in root $(P<0.05) . S t S n R K 2.4$ expression in leaf, stem and tuber were significantly higher than that in root. The expressions of StSnRK2.1, StSnRK2.2, StSnRK2.5, StSnRK2.6, $S t S n R K 2.7$ and $S t S n R K 2.8$ were lower in tubers than those in root.

\section{Stress-induced expression of StSnRK2s and physiological responses of potato plants}

Potato plantlets were treated with $\mathrm{H}_{2} \mathrm{O}$ (Control), ABA $(50 \mu \mathrm{M}), \mathrm{NaCl}(200 \mathrm{mM})$ and PEG-6000 (5\%). The total soluble sugar and proline contents were analyzed after $0 \mathrm{~h}, 2 \mathrm{~h}, 4 \mathrm{~h}, 6 \mathrm{~h}, 12 \mathrm{~h}, 24 \mathrm{~h}$ and $48 \mathrm{~h}$. The results indicated that ABA $(50 \mu \mathrm{M}), \mathrm{NaCl}(200 \mathrm{mM})$ and PEG-6000 (5\%) treatments increased the total soluble sugar and proline with prolonging of treatments (Additional file 2:
Figure S3). The relative gene expression of StSnRKs was analyzed using qRT-PCR. The results showed that the expression of all genes rose firstly after $\mathrm{NaCl}$ treatment, but different genes showed different responses to the stress condition (Fig. 6). StSnRK2.1 and StSnRK2.7 were similar and had their relative expression levels were highest at $12 \mathrm{~h}$ after subjected to the stress. Their expression levels gradually declined after $12 \mathrm{~h}$, but StSnRK2.1 had less reduction, and was significantly higher at $48 \mathrm{~h}$, while $S t S n R K 2.7$ declined greatest. The StSnRK2.2, StSnRK2.4 and StSnRK2.6 had similar expression trends. The relative expression levels of $S t S n R K 2.5$ and $S t S n R K 2.8$ increased rapidly after $2 \mathrm{~h}$ of treatments, and then began to fall to the levels lower than the control after the $6 \mathrm{~h}$, and remained at a relatively low expression. The relative expression level of $S t S n R K 2.3$ increased significantly $4 \mathrm{~h}$ after the stress, then began to decrease, but remained significantly high from 6 to $24 \mathrm{~h}$ and fell to the control level after $48 \mathrm{~h}$ of treatments, possibly indicating they have various signaling pathways.

Under PEG (5\%) treatment, the relative expression of StSnRK2.1, StSnRK2.2 and StSnRK2.3 rapidly rose after

Table 2 The secondary structure of StSnRK2 protein sequences. The secondary structure of the deduced polypeptide was predicted using the programs of SOPMA which listed in Expasy (www.EXPASY.org)

\begin{tabular}{lllll}
\hline Gene & Alpha helix (\%) & Extended strand (\%) & Beta turn (\%) & Random coil (\%) \\
\hline StSnRK2.1 & 42.39 & 16.42 & 7.46 & 33.73 \\
StSnRK2.2 & 43.36 & 16.22 & 6.78 & 33.63 \\
StSnRK2.3 & 38.12 & 17.40 & 7.46 & 37.02 \\
StSnRK2.4 & 47.22 & 15.56 & 9.17 & 28.06 \\
StSnRK2.5 & 34.59 & 19.19 & 6.69 & 39.53 \\
StSnRK2.6 & 43.02 & 13.41 & 5.31 & 38.27 \\
StSnRK2.7 & 43.45 & 15.48 & 4.17 & 36.90 \\
StSnRK2.8 & 38.68 & 16.62 & 7.16 & 37.54 \\
\hline
\end{tabular}




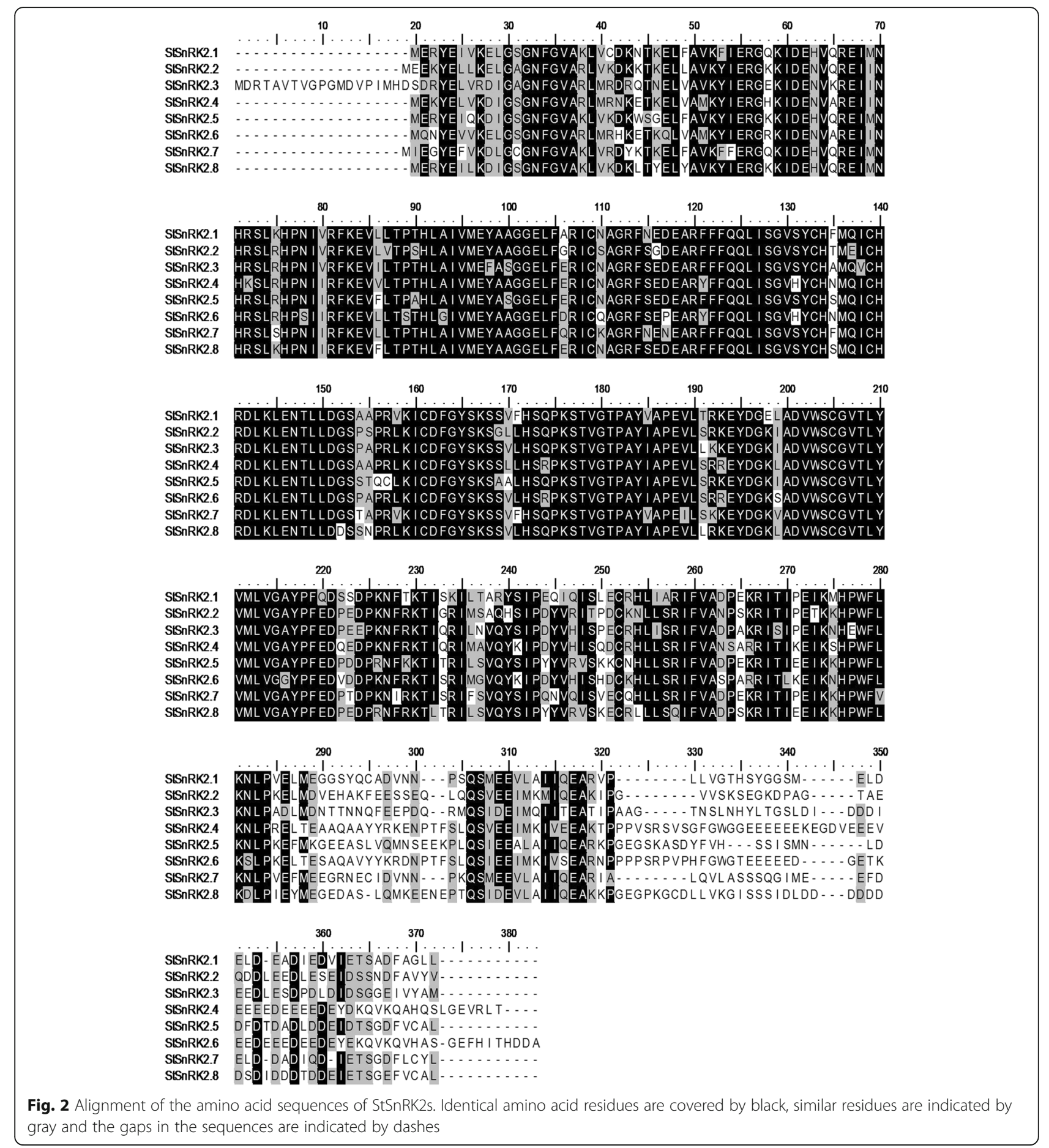

$2 \mathrm{~h}-4 \mathrm{~h}$ of treatment, and remained a relative stable level until $48 \mathrm{~h}$ (Fig. 7). StSnRK2.1 relative expression increased significantly after $4 \mathrm{~h}$, but the relative expression levels of StSnRK2.2 and StSnRK2.3 increased rapidly after $2 \mathrm{~h}$ of treatment. The relative expression levels of StSnRK2.4 and StSnRK2.5 rose rapidly, about five times of the control and reached a peak at $2 \mathrm{~h}$ of treatment, then declined significantly. The relative expression of
StSnRK2.6 declined slowly with the prolonging of treatment time; however, the relative expression of StSnRK2.8 was about seven times of the control at $4 \mathrm{~h}$ of treatment and then declined after $6 \mathrm{~h}$ of exposure to stress. StSnRK2.7 expression slowly increased with time until $12 \mathrm{~h}$ of treatment, then decreased significantly with no obvious difference compared to control at $24 \mathrm{~h}$ of treatment and to less than half of the control at $48 \mathrm{~h}$ of treatment. 


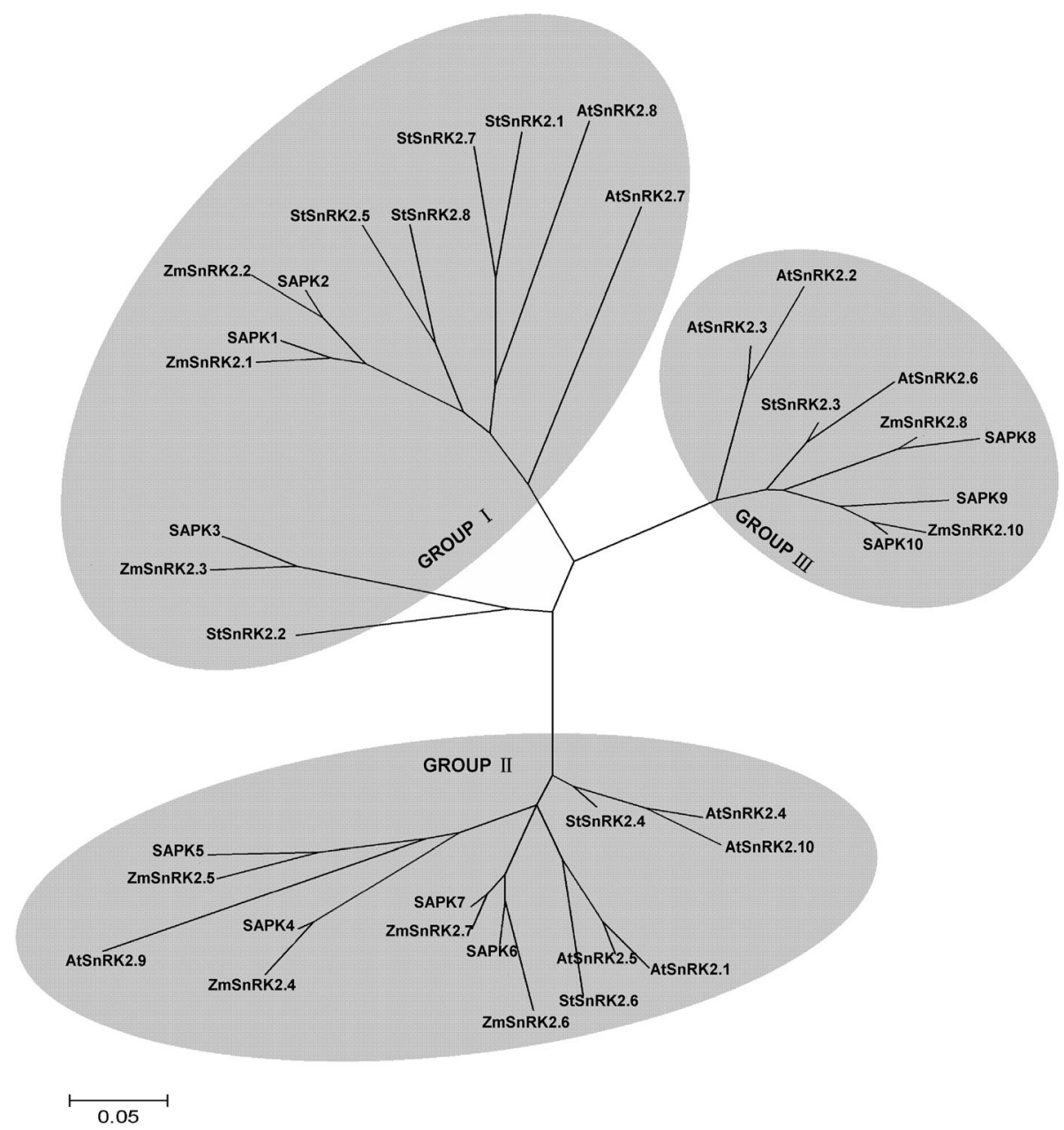

Fig. 3 A phylogenetic tree constructed with CluxtalX1.8 using the SnRK2s full length amino acid sequence from potato, Arabidopsis, rice and maize. The bootstrap analysis was performed using 1000 replicates in MEGA (5.0) to evaluate the reliability of different phylogenetic groups

The relative expression pattern of StSnRK2 genes under $\mathrm{ABA}$ treatment were different from $\mathrm{NaCl}$ and PEG treatments (Fig. 8). After $2 \mathrm{~h}$ of ABA, the relative expression level of StSnRK2.3 declined slightly, increased to a maximum after $6 \mathrm{~h}$ and then remained stable. Other members had no obvious changes in expression under ABA treatment, although the expression levels of StSnRK2.1, StSnRK2.5 and StSnRK2.7 declined slightly at $2 \mathrm{~h}$, but gradually returned to the control levels after $4 \mathrm{~h}$ of treatment. Compared to $\mathrm{NaCl}$ and PEG treatments, there was no significantly increasing trend. After $2 \mathrm{~h}$ of treatment, the expression levels of StSnRK2.2 and StSnRK2.4 also increased, but those of StSnRK2.6 and StSnRK2.8 had not changed. The results showed that StSnRK2 genes have no obvious response to ABA; most members of the subfamily may be involved in plant response pathways to stresses and were ABA-independent except that StSnRK2.3 is ABA-dependent.
To identify the presence of cis-elements in the promoter regions of the $S t S n R K 2 \mathrm{~s}$, the $2 \mathrm{~kb}$ length of the upstream region was considered as the promoter region and used to search for stress-responsive elements. We cloned eight StSnRK2 genes from the potato cultivar 'Longshu-3' and analyzed their location in the genome, gene structure, amino acid sequence divergence and tissue specific and stress-induced expression patterns. All genes except for StSnRK2.4 carried ABRE, StSnRK2.1, StSnRK2.2 and StSnRK2.4 carried DRE/CRT and StSnRK2.1, StSnRK2.2, StSnRK2.4, StSnRK2.5 and StSnRK2.7 had LTRE.

\section{Discussions}

The SnRK2 subfamily is an osmotic-stress activated protein kinase and has been identified and characterized in Arabidopsis, rice, maize and other plant species. Many studies have showed that SnRK2 members have potential 


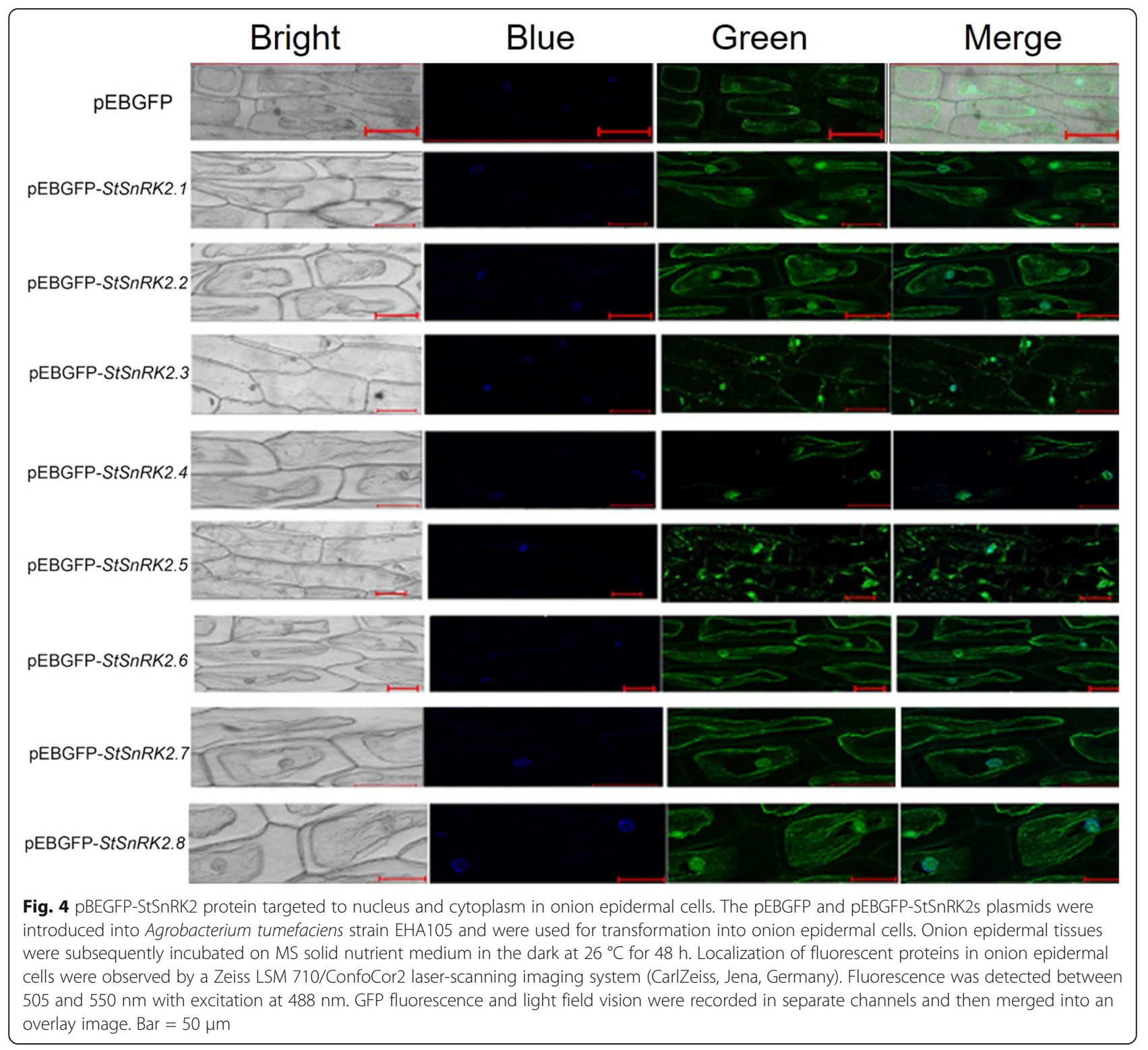

roles in improving stress tolerance and increase crop yields $[29,32]$. In the present study, we identified and cloned eight StSnRK2 genes from potato cultivar 'Longshu-3', and analyzed their genome distribution, gene structure, phylogenic and tissue specific and stress-induced expression patterns. Similar to $S n R K 2 s$ in Arabidopsis, rice and maize, StSnRK2 genes in potato were distributed over several chromosomes. All the $S t S n R K 2 s$ except for $S t S n R K 2.6$ have nine exons, similar to the $S n R K 2 s$ in other plant species $[26,46]$. The functional characteristics of the C-terminal region of $S n R K 2 s$ has been reported in several plant species like Arabidopsis [4, 5, 13, 14, 16, 17, 35], rice $[25,36]$ and maize $[26,47]$. The evolutionary distance

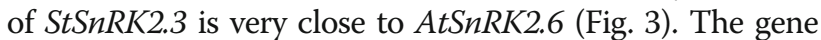
products of AtSnRK2.2 and AtSnRK2.3 are mostly concentrated in leaves, contributing largely to the ABAdependent stomatal regulation $[4,15]$.

Tissue-specific expression of $S n R K 2$ genes were observed in many species. For example, fava bean AAPKs induced by $\mathrm{ABA}$ signaling were mainly expressed in guard cells [48]. The expression of SAPK members is different among tissues in rice: $S A P K 8,9$ and 10 are regulated only by ABA in blades and roots, with the level of expression in roots higher than in other tissues [25]. Root tips, as a dynamic and specialized tissue, play a crucial role in sensing water and nutrients and often have rapid responses by transmitting appropriate signals. In current study, the expressions of $S t S n R K 2 s$ in various tissues of potato plantlets were highly diversified and these proteins may mediate various metabolic processes 


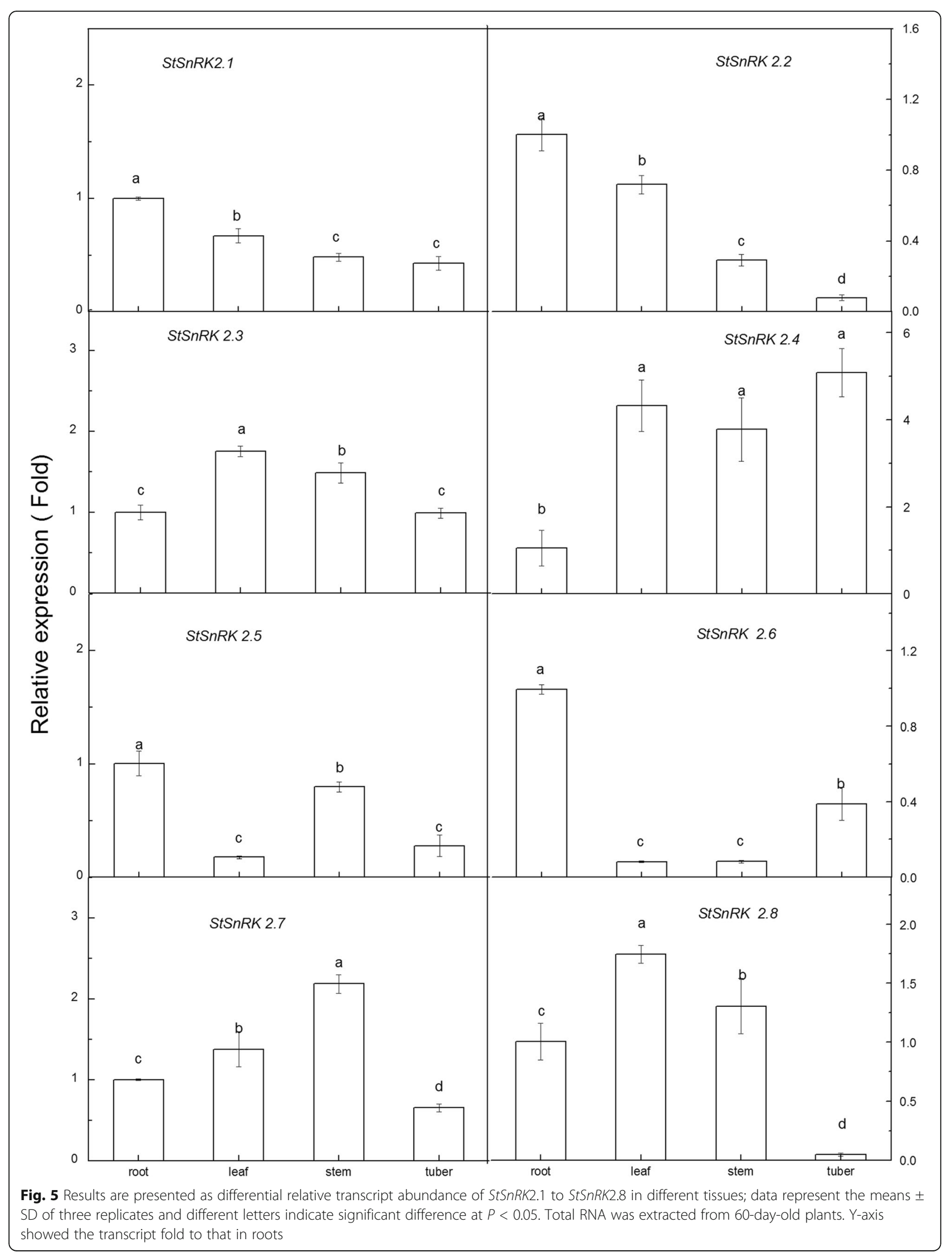




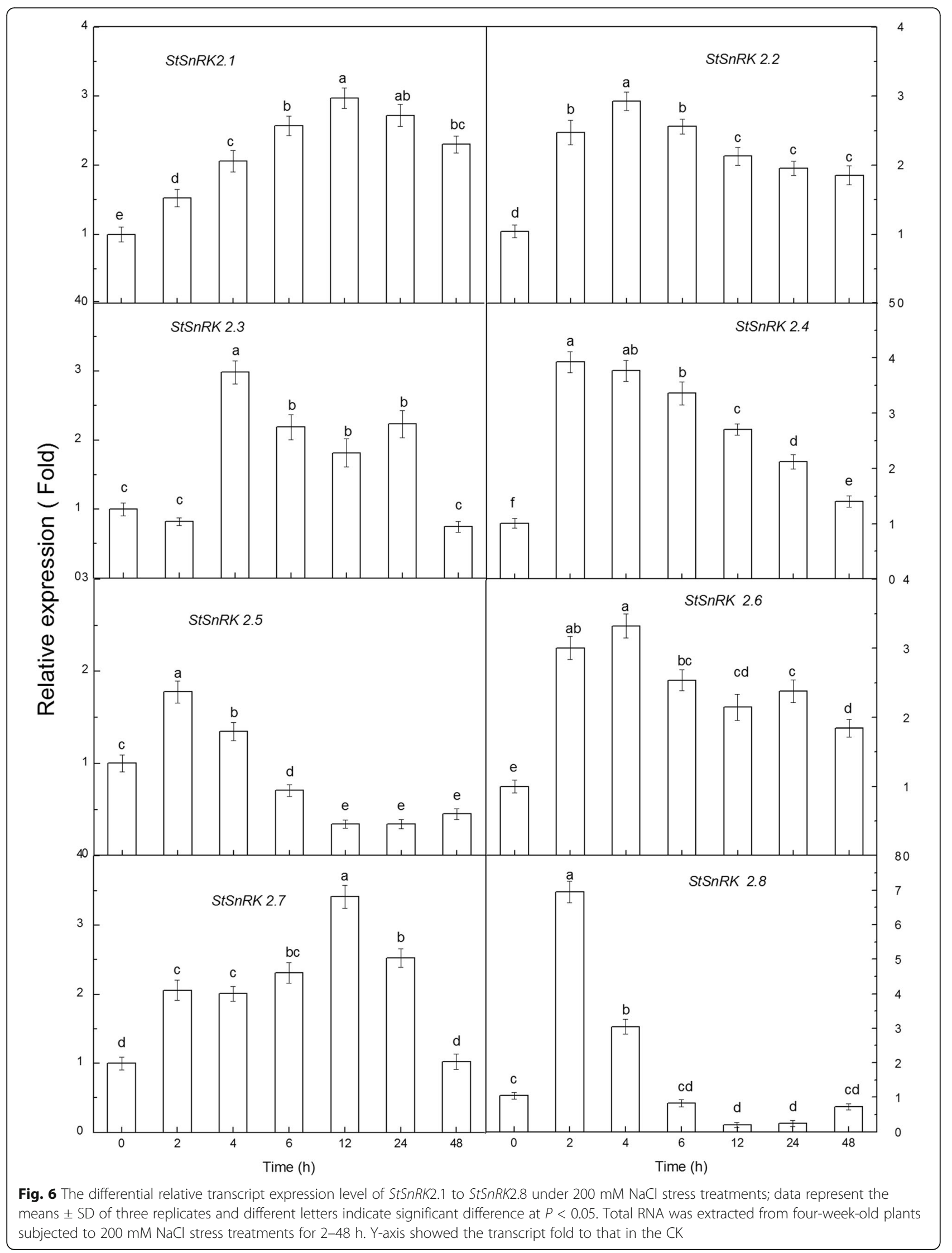




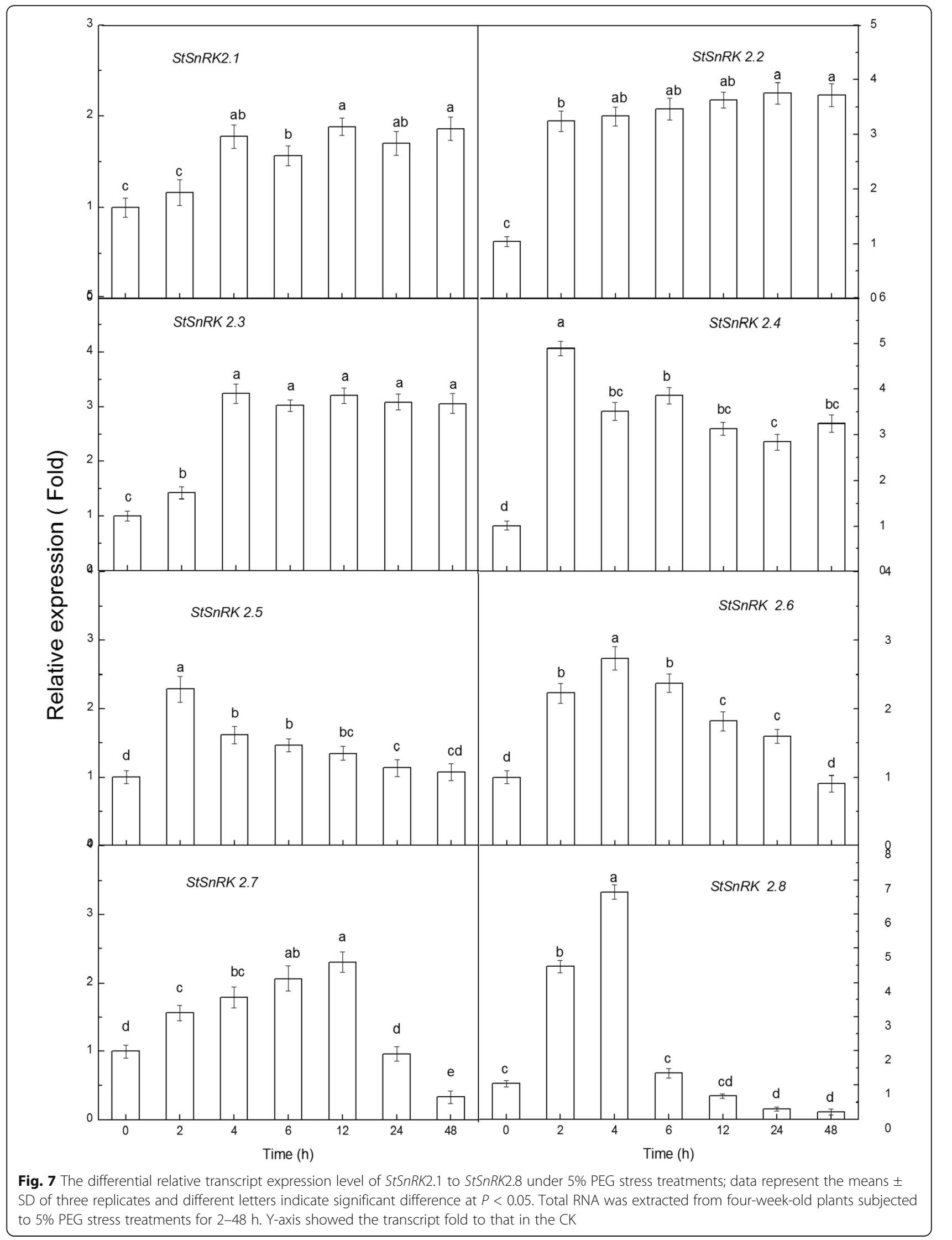




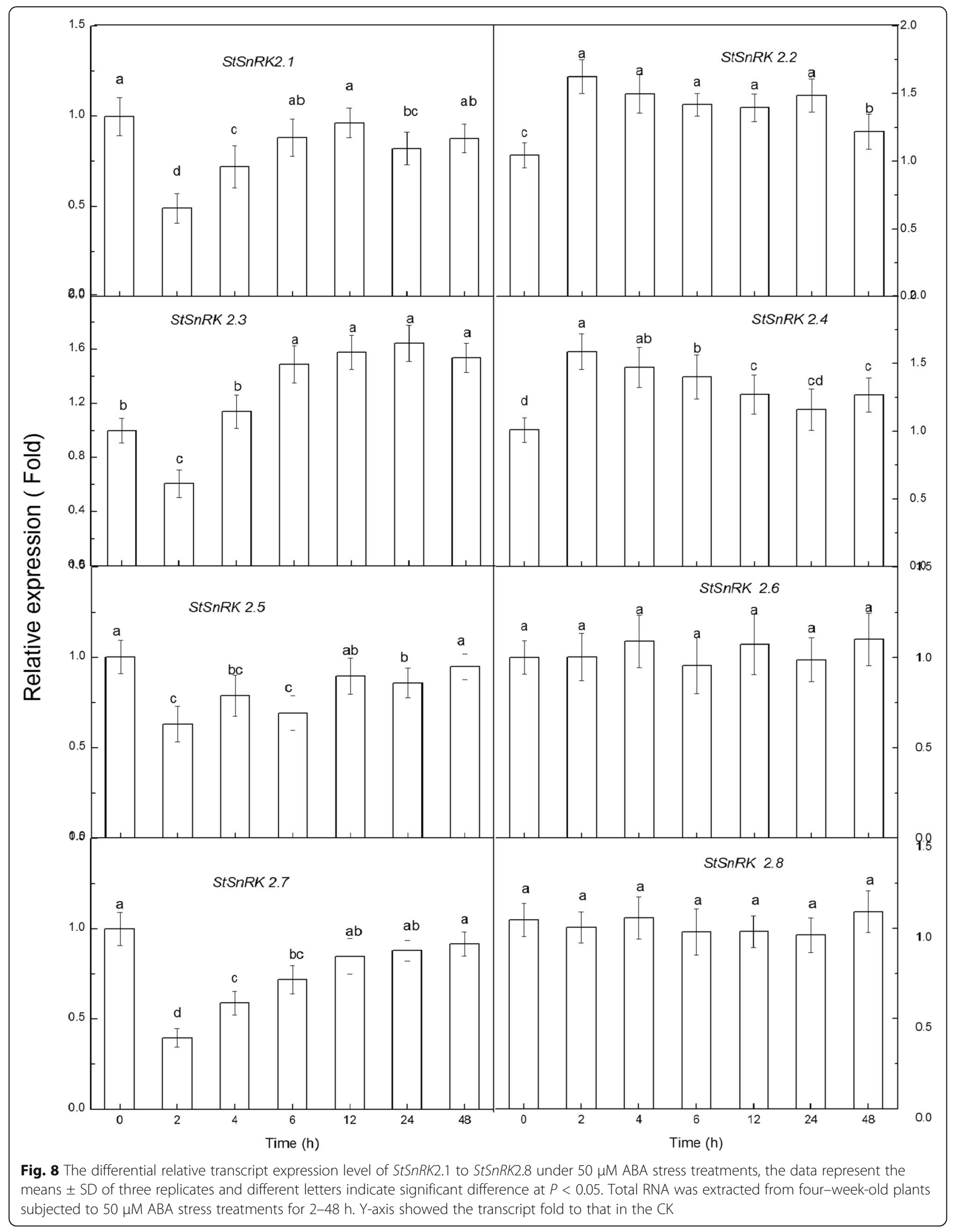


under normal growing conditions. The expression of StSnRK2.4 was higher in shoot tissues than in roots, and could be induced by $\mathrm{NaCl}$, ABA and PEG (Figs. 5, 6, 7, 8), suggesting that StSnRK2.4 may be sensitive to stress signals and function in osmotic-stress responses in shoot tissues of potato. The expression of TaSnRK2.4 was stimulated by high salt treatments, and the overexpression of TaSnRK2.4 in Arabidopsis enhanced salt tolerance [28]. StSnRK2.4 and AtSnRK2.4 were classified into the same group, implying that StSnRK2.4 may be a potential target for improving the salt tolerance of potato. In Arabidopsis, SnRK2.2, SnRK2.3 and SnRK2.6 are typically activated by ABA, and can phosphorylate the ABA-responsive elements. So, they are important for the activation of ABA-responsive genes. In rice, SAPK8, 9, and 10 are activated by ABA [25]. The regulation of the plant responses to ABA via SnRK2s pathways occurs by direct phosphorylation of various downstream targets, for example, SLAC1, KAT1, AtRbohF and transcription factors were required for the expression of numerous stress response genes [46]. The expression of ZmSnRK2 genes can be induced by various stress treatments, suggesting their potential roles in stress responses. We found that each gene of $S t S n R K 2$ subfamily has a unique expression pattern in different tissues of potato, with the expressions of StSnRK2.2 and StSnRK2.8 very low in roots, whereas the expressions of StSnRK2.5 and StSnRK2.6 were very low in leaves. However, they were insensitive to ABA treatments, probably due to the different regulatory elements that each StSnRK2 carried on the 2-kb upstream region (Table 3). Alternatively, the concentration of ABA and the prolonging of the ABA treatment need to be further discussed. The manipulation of StSnRK2s can be a valuable approach for improving the stress tolerance of potato.

Table 3 Putative Cis elements existed in the $2 \mathrm{~kb}$ upstream region of StSnRK2 genes

\begin{tabular}{llll}
\hline Name & ABRE & DRE/CRT & LTRE \\
\hline StSnRK2.1 & 4 & 1 & 1 \\
StSnRK2.2 & 3 & 2 & 1 \\
StSnRK2.3 & 1 & 0 & 0 \\
StSnRK2.4 & 0 & 2 & 2 \\
StSnRK2.5 & 2 & 0 & 2 \\
StSnRK2.6 & 2 & 0 & 0 \\
StSnRK2.7 & 3 & 0 & 1 \\
StSnRK2.8 & 5 & 0 & 0
\end{tabular}

The sequence of ABRE elements include ACGTG, MACGYGB, TACGTGTC, YACGTGGC, and CCACGTGG. The sequence of DRE/CRT element include RCCGAC, ACCGAC, ACCGAGA and GTCGAC. The sequences of LTRE element include CCGAC, CCGAAA, ACCGACA and CCGAC

\section{Conclusions}

In the present study, we identified and characterized eight $\operatorname{SnRK2}$ genes in the potato genome. The eight StSnRK2s exhibit similar gene structure and secondary structures in potato to the $S n R K 2 s$ found in other plant species. The fluorescence of GFP fused with StSnRK2.1, StSnRK2.2, StSnRK2.6, StSnRK2.7, and StSnRK2.8 was detected in the nucleus and cytoplasm of onion epidermal cells. On the other hand, StSnRK2.3 and StSnRK2.4 are mainly associated to the nucleus, while StSnRK2.5 seems to be associated to subcellular organelles. The relative expression of the eight $S n R K 2$ genes varied among tissues (roots, leaves, tubers and stems) and abiotic stresses (ABA, $\mathrm{NaCl}$ and PEG-6000) with the prolonging of treatments. This study provides valuable information for the future functional dissection of potato $S n R K 2$ genes in stress signal transduction, plant growth and development studies.

\section{Additional files}

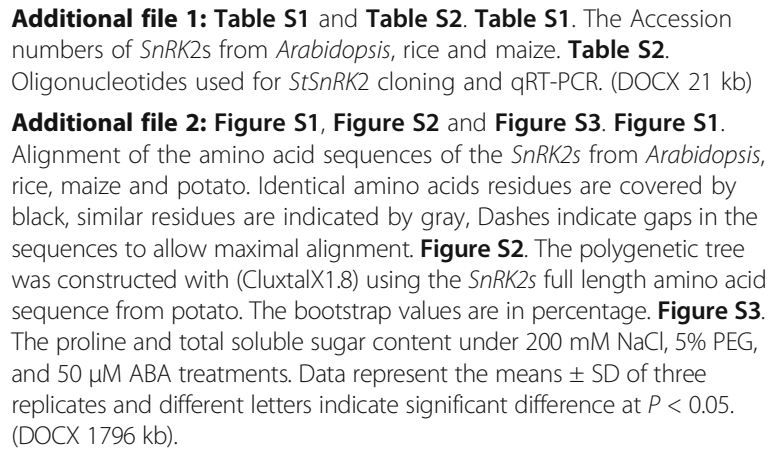
rice, maize and potato. Identical amino acids residues are covered by black, similar residues are indicated by gray, Dashes indicate gaps in the sequences to allow maximal alignment. Figure S2. The polygenetic tree was constructed with (CluxtalX1.8) using the SnRK2s full length amino acid sequence from potato. The bootstrap values are in percentage. Figure S3. The proline and total soluble sugar content under $200 \mathrm{mM} \mathrm{NaCl}, 5 \%$ PEG, and $50 \mu \mathrm{M}$ ABA treatments. Data represent the means \pm SD of three replicates and different letters indicate significant difference at $P<0.05$. (DOCX $1796 \mathrm{~kb})$.

\section{Abbreviations}

ABA: Abscisic acid; NaCl: Sodium chloride; PEG-6000: Polyethyleneglycol6000; qRT-PCR: Quantitative real-time PCR; SnRK: Sucrose non-ferment 1 related protein kinase

\section{Acknowledgments}

We would like to thank Professor Yantai Gan for valuable discussion on the conception of the manuscript.

\section{Funding}

This research was supported by the Key Project of Gansu Province Programs for Fundamental Research and Development (grant No. 1102NKDA025), the National Natural Science Foundation of China (grant No. 31460369) and Longyuan Young Scientist Supporting Program.

\section{Availability of data and materials}

All data and supporting information from this paper will be available and freely distributed by corresponding authors.

\section{Authors' contributions}

$\mathrm{JB}$ was in charge of experiment design and manuscript prepareation; JM was responsable for the gene cloning, qRT-PCR experiments and data analysis; HY was responsable for subcellular localization of StSnRK2 proteins; AK contributed in the data analysis and manuscript preparation; AF, SL and HG helped with the sample preparation and data collection and analysis; Junlian Zhang and DW contributed to the lab orgnization and supervision of the overall progress of the project. Jinlin Zhang contributed to the experimental 
design, data analysis and manuscript writing and revision. All the authors have read and approved the final manuscript.

\section{Competing interests}

The authors declare that they have no competing interests.

\section{Consent for publication}

Not applicable.

\section{Ethics approval and consent to participate}

No human participants, human data or human tissue were involved in this study. No animals were used in this study.

\section{Publisher's Note}

Springer Nature remains neutral with regard to jurisdictional claims in published maps and institutional affiliations.

\section{Author details}

${ }^{1}$ Gansu Key Lab of Crop Improvement \& Germplasm Enhancement, Gansu Provincial Key Lab of Aridland Crop Science, Lanzhou 730070, Gansu, People's Republic of China. ${ }^{2}$ College of Agronomy, Gansu Agricultural University, Lanzhou 730070, Gansu, People's Republic of China. ${ }^{3}$ College of Horticulture, Gansu Agricultural University, Lanzhou 730070, Gansu, People's Republic of China. ${ }^{4}$ International Potato Center (CIP), Avenida La Molina 1895, La Molina Apartado, 1558 Lima, Peru. ${ }^{5}$ State Key Laboratory of Grassland Agro-ecosystems, College of Pastoral Agriculture Science and Technology, Lanzhou University, Lanzhou 730020, Gansu, People's Republic of China.

\section{Received: 11 May 2016 Accepted: 8 May 2017}

\section{Published online: 15 May 2017}

\section{References}

1. Hu XJ, Zhang ZB, Xu P, Fu ZY, Hu SB, Song WY. Multifunctional genes: the cross-talk among the regulation networks of abiotic stress responses. Biol Plant. 2010:54:213-23.

2. Thapa G, Dey M, Sahoo L, Panda SK. An insight into the drought stress induced alterations in plants. Biol Plant. 2011;55:603-13.

3. Laurie $S$, Halford NG. The role of protein kinases in the regulation of plant growth and development. Plant Growth Regul. 2001;34:253-65.

4. Yoshida T, Nishimura N, Kitahata N, Kuromori T, Ito T, Asami T, Shinozaki K, Hirayama T. ABA-hypersensitive germination3 encodes a protein phosphatase 2C (AtPP2CA) that strongly regulates abscisic acid signaling during germination among Arabidopsis protein phosphatase 2Cs. Plant Physiol. 2006;140:115-26.

5. Fujii $H$, Verslues PE, Zhu JK. Identification of two protein kinases required for abscisic acid regulation of seed germination, root growth, and gene expression in Arabidopsis. Plant Cell. 2007;19:485-94.

6. Movahed S, Sayed Tabatabaei BE, Alizade H, Ghobadi C, Yamchi A, Khaksar G. Constitutive expression of Arabidopsis DREB1B in transgenic potato enhances drought and freezing tolerance. Biol Plant. 2012;56:37-42.

7. Hong L, Hu B, Liu X, He CY, Yao Y, Li XL, Li L. Molecular cloning and expression analysis of a new stress-related $A R E B$ gene from Arachis hypogaea. Biol Plant. 2013;57:56-62

8. Qin F, Shinozaki K, Yamaguchi-Shinozaki K. Achievements and challenges in understanding plant abiotic stress responses and tolerance. Plant Cell Physiol. 2011;52:1569-82.

9. $\quad$ Bing L, Feng CC, Li JL, Li XX, Zhao BC, Shen YZ, Huang ZJ, Ge R. Overexpression of the AtSTK gene increases salt, PEG and ABA tolerance in Arabidopsis. J Plant Biol. 2013;56:375-82.

10. Tao XC, Lu YT. Loss of AtCRK1 gene function in Arabidopsis thaliana decreases tolerance to salt. J Plant Biol. 2013;56:306-14.

11. Halford NG, Hardie DG. SNF1-related protein kinases: glob al regulators of carbon metabolism in plants? Plant Mol Biol. 1998;37:735-48.

12. Ghillebert R, Swinnen E, Wen J, Vandesteene L, Ramon M, Norga K, Rolland F, Winderickx J. The AMPK / SNF1 / SnRK1 fuel gauge and energy regulator: structure, function and regulation. FEBS J. 2011:278:3978-90.

13. Boudsocq $M$, Barbier-Brygoo $H$, Lauriere $C$. Identification of nine sucrose nonfermenting 1-related protein kinases 2 activated by hyper osmotic and saline stresses in Arabidopsis thaliana. J Biol Chem. 2004;279:41758-66.
14. Umezawa T, Yoshida R, Maruyama K, Yamaguchi-Shinozaki K, Shinozaki K. SRK2C, a SNF1-related protein kinase 2, improves drought tolerance by controlling stress-responsive gene expression in Arabidopsis thaliana. Proc Natl Acad Sci USA. 2004;101:17306-11.

15. Fujii H, Zhu JK. Arabidopsis mutant deficient in 3 abscisic acid-activated protein kinases reveals critical roles in growth, reproduction, and stress. Proc Natl Acad Sci USA. 2009;106:8380-5.

16. Fujii H, Verslues PE, Zhu JK. Arabidopsis decuple mutant reveals the importance of SnRK2 kinases in osmotic stress responses in vivo. Proc Natl Acad Sci USA. 2011;108:1717-22.

17. Mustilli AC, Merlot S, Vavasseur A, Fenzi F, Giraudat J. Arabidopsis OST1 protein kinase mediates the regulation of stomatal aperture by abscisic acid and acts upstream of reactive oxygen species production. Plant Cell. 2002; 14:3089-99.

18. Sun L, Zhang M, Ren J, Qi JX, Zhang GJ, Leng P. Reciprocity between abscisic acid and ethylene at the onset of berry ripening and after harvest. BMC Plant Biol. 2010;10:257-67.

19. Zheng Z, Xu X, Crosley RA, Greenwalt SA, Sun Y, Blakeslee B, Wang L, Sopko MS, Yao C, Yau K, Burton S, Zhuang M, McCaskill DG, Gachotte D, Thompson M, Greene TW. The protein kinase SnRK2.6 mediates the regulation of sucrose metabolism and plant growth in Arabidopsis. Plant Physiol. 2010;153:99-113.

20. Johnson RR, Wagner RL, Verhey SD, Walker-Simmons MK. The abscisic acidresponsive kinase PKABA1 interacts with a seed-specific abscisic acid response element-binding factor, TaABF, and phosphorylates TaABF peptide sequences. Plant Physiol. 2002;130:837-46.

21. Nakashima K, Fujita Y, Kanamori N, Katagiri T, Umezawa T, Kidokoro S, Maruyama K, Yoshida T, Ishiyama K, Kobayashi M, Shinozaki K, Yamaguchi-Shinozaki K. Three Arabidopsis SnRK2 protein kinases, SRK2D/SnRK2.2, SRK2E/SnRK2.6/OST1 and SRK21/SnRK2.3, involved in ABA signaling are essential for the control of seed development and dormancy. Plant Cell Physiol. 2009;50:1345-63.

22. Anderberg RJ, Walker-Simmons MK. Isolation of a wheat CDNA clone for an abscisic acid-inducible transcript with homology to protein kinases. Proc Natl Acad Sci USA. 1992:89:10183-7.

23. Li J, Assmann SM. An abscisic acid-activated and calcium-independent protein kinase from guard cells of fava bean. Plant Cell. 1996:8:2359-68.

24. McLoughlin F, Galvan-Ampudia CS, Julkowska MM, Caarls L, Does D, Lauriere C, Munnik T, Haring MA, Testerink C. The Snf1-related protein kinases SnRK2.4 and SnRK2.10 are involved in maintenance of root system architecture during salt stress. Plant J. 2012;72:436-49.

25. Kobayashi Y, Yamamoto S, Minami H, Kagaya Y, Hattor T. Differential activation of the rice sucrose nonfermenting1-related protein kinase 2 family by hyperosmotic stress and abscisic acid. Plant Cell. 2004;16:1163-77.

26. Huai JL, Wang M, He JG, Zheng J, Dong ZG, Lv HK, Zhao JF, Wang GY Cloning and characterization of the SnRK2 gene family from Zea mays. Plant Cell Rep. 2008;28:1861-8

27. Kelne A, Pekala I, Kaczanowski S, Muszynska G, Hardie DG, Dobrowolska G. Biochemical characterization of the tobacco $42-\mathrm{kD}$ protein kinase activated by osmotic stress. Plant Physiol. 2004;136:3255-65.

28. Mao XG, Zhang HY, Tian SJ, Chang XP, Jing RL. TaSnRK2.4, an SNF1-type serine/threonine protein kinase of wheat (Triticum aestivum L.), confers enhanced multistress tolerance in Arabidopsis. J Exp Bot. 2010;61:683-96.

29. Zhang HY, Mao XG, Jing RL, Chang XP, Xie HM. Characterization of a common wheat (Triticum aestivum L.) TaSnRK2.7 gene involved in abiotic stress responses. J Exp Bot. 2011:62:975-88.

30. Li LB, Zhang YR, Liu KC, Ni ZF, Fang ZJ, Sun QX, Gao JW. Identification and bioinformatics analysis of SnRK2 and CIPK family genes in Sorghum. Agr Sci China. 2010;9:19-30.

31. Monks DE, Aghoram K, Courtney PD, DeWald DB, Dewey RE. Hyperosmotic stress induces the rapid phosphorylation of a soybean phosphatidylinositol transfer protein homolog through activation of the protein kinases SPK and SPK2. Plant Cell. 2001:13:1205-19.

32. Yang L, Ji W, Gao P, Li Y, Cai H, Bai X, Chen Q, Zhu Y. GsAPK, an ABAactivated and calcium-independent SnRK2-type kinase from G. soja, mediates the regulation of plant tolerance to salinity and ABA stress. PLoS One. 2012;7:e33838

33. Yamauchi D, Zentella R, Ho TD. Molecular analysis of the barley (Hordeum vulgare L.) gene encoding the protein kinase PKABA1 capable of suppressing gibberellin action in aleurone layers. Planta. 2002;215:319-26.

34. Boneh U, Biton I, Schwartz A, Ben-Ari G. Characterization of the ABA signal transduction pathway in Vitis vinifera. Plant Sci. 2012;187:89-96. 
35. Mizoguchi M, Umezawa T, Nakashima K, Kidokoro S, Takasaki H, Fujita Y, Yamaguchi-Shinozakj K, Shinozaki K. Two closely related subclass II SnRK2 protein kinases cooperatively regulate drought-inducible gene expression. Plant Cell Physiol. 2010;51:842-7.

36. Kobayashi $Y$, Murata M, Minami H, Yamamoto S, Kagaya Y, Hobo T, Yamamoto A, Hattori T. Abscisic acid-activated SNRK2 protein kinases function in the gene-regulation pathway of ABA signal transduction by phosphorylating ABA response element-binding factors. Plant J. 2005;44: 939-49.

37. Murashige T, Skoog F. A revised medium for rapid growth and bioassay with tobacco tissue cultures. Physiol Plantarum. 1962;15:473-97.

38. Waterhouse AM, Procter JB, Martin DMA, Clamp M, Barton GJ. Jalview Version 2-a multiple sequence alignment editor and analysis workbench. Bioinformatics. 2009;25:1189-91.

39. Tamura K, Peterson D, Peterson N, Stecher G, Nei M, Kumar S. MEGA5: molecular evolutionary genetics analysis using maximum likelihood, evolutionary distance, and maximum parsimony methods. Mol Biol Evol. 2011;28:2731-9.

40. Kapustin Y, Souvorov A, Tatusova T, Lipman D. Splign: algorithms for computing spliced alignments with identification of paralogs. Biol Direct. 2008:3:1-13.

41. Higo $\mathrm{K}$, Ugawa $\mathrm{Y}$, Iwamoto M, Korenaga T. Plant cis-acting regulatory DNA elements (PLACE) database. Nucleic Acids Res. 1999;27:297-300.

42. Livak KJ, Schmittgen TD. Analysis of relative gene expression data using real-time quantitative and the $2^{-\Delta \Delta C} T$ method. Methods. 2001;25:402-8.

43. Willems $E$, Leyns $L$, Vandesompele J. Standardization of real-time PCR gene expression data from independent biological replicates. Anal Biochem. 2008:379:127-9

44. Zhang SJ, Li N, Gao F, Yang AF, Zhang JR. Over-expression of TSCBF1 gene confers improved drought tolerance in transgenic maize. Mol Breed. 2010; 26:455-65.

45. Bates $L S$, Waldren RP, Teare ID. Rapid determination of free proline for water-stress studies. Plant Soil. 1973;39:205-7.

46. Kulik A, Wawer I, Krzywińska E, Bucholc M, Dobrowolska G. SnRK2 protein kinases-key regulators of plant response to abiotic stresses. OMICS. 2011; 15:859-72.

47. Ying S, Zhang DF, Li HY, Liu YH, Shi YS, Song YC, Wang TY, Li Y. Cloning and characterization of a maize SnRK2 protein kinase gene confers enhanced salt tolerance in transgenic Arabidopsis. Plant Cell Rep. 2011;30:1683-99.

48. Li J, Wang XQ, Watson MB, Assmann SM. Regulation of abscisic acidinduced stomatal closure and anion channels by guard cell AAPK kinase. Science. 2000;287:300-3.

\section{Submit your next manuscript to BioMed Central and we will help you at every step:}

- We accept pre-submission inquiries

- Our selector tool helps you to find the most relevant journal

- We provide round the clock customer support

- Convenient online submission

- Thorough peer review

- Inclusion in PubMed and all major indexing services

- Maximum visibility for your research

Submit your manuscript at www.biomedcentral.com/submit

C) Biomed Central 